\title{
Komunikasi dan Pembangunan Partisipatif
}

\author{
Rini Rinawati \\ ABSTRACT \\ A participatory development philosophy has shifted the traditional linear development. Through \\ the new development principles, hopefully, members of village might actively participate \\ in development process. The program called Community Action Plan (CAP) \\ based on community participation releases document such as Mid-term Development Plan \\ on the level of village. Communication system is needed to help people transforming their goals, \\ values, and cultural beliefs into the plan.
}

Kata kunci: pembangunan partisipatoris, "Community Action Plan," masyarakat desa

\section{Pendahuluan}

Pembangunan sebagai suatu kegiatan nyata dan berencana menjadi menonjol sejak selesainya Perang Dunia II. Bagi negara yang baru terlepas dari belenggu penjajahan dan kemudian merdeka, menjadi suatu keharusan untuk menyelenggarakan pembangunan bagi negaranya. Sejak itulah berkembang berbagai rencana pembangunan yang menjadi pegangan bagi negara. Pembangunan itu sendiri bertujuan untuk secepatnya mengejar ketertinggalan dari negara maju.

Paradigma pembangunan Indonesia sendiri pada awalnya memandang pembangunan sebagai suatu perspektif yang tunggal dan evolusioner. Dalam paradigma ini, pembangunan diartikan sebagai "jenis perubahan sosial di mana ide-ide baru diperkenalkan kepada suatu sistem sosial untuk menghasilkan pendapatan per kapita dan tingkat kehidupan yang lebih tinggi melalui metode produksi yang lebih modern dan organisasi sosial yang lebih baik" (Roger \& Shoemaker, dalam Nasutioan,1996:28).

Sebagai upaya yang bersifat evolusioner dan dalam rangka mengejar ketinggalan dari negara maju, maka suka tidak suka, disadari atau tidak disadari, paradigma pembangunan identik dengan pembangunan ekonomi. Dalam hal ini, tujuan pembangunan nasional adalah mencapai pertumbuhan ekonomi yang setinggi-tingginya, dan pembangunan ekonomi dipandang sebagai strategi investasi.

Namun, pembangunan ini banyak mendapat kritikan, karena ternyata pembangunan yang hanya menitikberatkan pada sektor ekonomi telah membawa berbagai akibat yang negatif, seperti kerusakan alam, timbulnya kesenjangan sosial, dan dependensi (Tjokrowinoto, 1996:9).

Lahirlah konsep-konsep baru mengenai pembangunan yang tidak hanya menitikberatkan pada sektor ekonomi, seperti pembangunan berkelanjutan, pembangunan berwawasan lingkungan. Sekalipun pembangunan tersebut berbeda, namun terdapat kesamaan, yaitu bahwa perencanaan dari pembangunan tersebut dilaksanakan oleh pemerintah beserta aparatnya. Dalam paradigma pembangunan di atas masyarakat hanya dijadikan sebagai objek dari pembangunan.

Masyarakat sebagai objek tidak diikutsertakan 
dalam pembangunan tersebut. Mereka hanya menikmati hasilnya saja. Celakanya, pembangunan yang ditujukan untuk masyarakat tersebut seringkali tidak dibutuhkan oleh mereka.

Hal ini dikarenakan perencanaan dari pembangunan tersebut bukan merupakan kebutuhan yang lahir dari masyarakat, akan tetapi merupakan kebutuhan segelintir orang dengan berbagai kepentingan. Sebagai contoh saja, sering kali sebuah jalan dibangun hanya karena ada rumah pejabat di daerah tersebut. Irigasi diusulkan dan kemudian direalisasi hanya karena melewati kebun atau sawah pejabat, dan masih banyak contoh lainnya.

Pembangunan dengan paradigma inilah yang kemudian banyak dikritik. Salah satunya adalah bahwa (Susanto, 1995:22-23):

(1) Pembangunan desa selalu dilihat hanya dari segi difusi inovasi

(2) dilupakan bahwa proses pembangunan ialah pengadaan suatu sistem nilai baru dan berhubungan dengan pengadaan keterampilan demi perbaikan hidup

(3) sikap selalu menitikberatkan dan membebankan tugas pembangunan dan perencanaan pembangunan kepada aparatur pemerintah

(4) terlupakan bahwa proses pembangunan mencakup proses yang kompleks dan bukan merupakan proses yang linier.

Oleh karena itu, sejak era reformasi bergulir, dan juga sejak dicanangkannya otonomi daerah, maka paradigma pembangunan mengalami perubahan pula. Pembangunan tidak hanya bersifat linier dan tidak hanya melibatkan aparatur pemerintahan saja. Paradigma pembangunan menjadi "pembangunan partisipatif".

Dalam pembangunan partisipatif, masyarakat yang ada di desa menjadi ujung tombak dari sebuah pembangunan. Oleh karena itu, masyarakat yang ada di desa diharapkan dapat secara aktif berperan serta dalam menentukan arah membangunan bagi desanya.

Bagi desa, hal ini tentu amat penting. Desa, selain sebagai penyangga utama dari pemerintahan kabupaten dalam mencapai visi dan misi daerahnya, dalam hal ini juga merupakan institusi yang paling dekat dan dirasakan langsung oleh masyarakat. Selama ini memang telah ada perencanaan pembangunan di desa (RPJMD), namun seringkali tidak mencerminkan aspirasi dari masyarakat, bahkan banyak sekali desa yang belum memiliki rencana pembangunannya.

Atas dasar itulah maka diperkenalkan sebuah program yang dikenal dengan sebutan CAP (community action plan), sebuah program perencanaan pembangunan yang berbasis partisipasi masyarakat (komunitas). Program ini bertujuan mendorong setiap individu dapat bertindak bagi lingkungannya, baik dengan cara mengubah kehidupannya atau dengan berpartisipasi dalam kegiatan-kegiatan yang berbasis komunitas.

CAP tingkat desa merupakan dokumen rencana jangka menengah desa dalam rangka mengatasi atau memecahkan permasalahan prioritas di desa. Rencana tindak ini berisi indikasiindikasi kegiatan yang konkret dan realistis untuk dilaksanakan sesuai dengan kemampuan desa/ kelurahan untuk melaksanakananya. Kegiatankegiatan yang ada dalam CAP desa/kelurahan tersebut merupakan kegiatan yang disepakati dan prioritas dilakukan untuk menjawab permasalahanpermasalahan prioritas desa yang telah dirumuskan dan disepakati bersama.

Melihat pada arah dari paradigma pembangunan yang sekarang dicanangkan, dan juga melihat pada program yang dijalankan dalam membuat rencana pembangunan tersebut, maka diperlukan keahlian komunikasi untuk menyosialisasikan program ini, juga dapat mengajak (memotivasi) dan menggerakkan masyarakat agar mau berpartisipasi dalam merencanakan pembangunan di desanya.

Komunikasi memang dapat dilakukan oleh semua orang. Akan tetapi, tidak semua orang dapat mengomunikasi sesuatu (pesan) secara efektif, lebih jauh lagi memotivasi untuk mengerakkan masyarakat.

Dari permasalahan di atas maka penulis mencoba untuk menelaah dan memaparkan "sejauh mana peranan komunikasi dalam kerangka pembangunan partisipatif?"' 


\section{Tinjauan Teoretis}

\subsection{Pengertian Komunikasi}

Manusia telah berkomunikasi selama puluhan ribu tahun. Sebagian besar waktu jaga manusia digunakan untuk berkomunikasi. Meskipun demikian, ketika manusia dilahirkan tidak dengan sendirinya dibekali kemampuan untuk berkomunikasi secara efektif. Kemampuan seperti itu bukan bawaan, melainkan dipelajari.

Setiap orang, terlepas apapun tujuan dalam hidupnya, harus memperoleh tingkat minimum keterampilan berkomunikasi untuk bertahan hidup. Komunikasi begitu penting bagi setiap aspek kehidupan yang penuh dan memuaskan. Karenanya penting bagi kita untuk memperoleh lebih dari pada keefektifan minimun (Forest dan Olson, dalam Tubbs \& Moss, 1996:X).

Terdapat beberapa pemahaman para ahli terhadap komunikasi, diantaranya;

- Carl I.Hovland yang mendefinisikan komunikasi sebagai "proses yang memungkinkan seseorang untuk menyampaikan rangsangan untuk mengubah perilaku orang lain”.

- Sementara, Theodore M.Newcomb memahami komunikasi sebagai"suatu transmisi informasi, terdiri dari rangsangan yang diskriminatif dari sumber kepada penerima".

- Harold Lasswel menjelaskan komunikasi dengan mencoba untuk menjawab pertanyaan "who says what in which cahnnel to whom with what effect?"

Dari beberapa pemahaman tentang komunikasi tersebut, terdapat satu kesamaan, yaitu bahwa komunikasi merupakan proses penyampaian pernyataan manusia. Yang dinyatakan itu adalah pikiran atau perasaan seseorang kepada orang lain dengan menggunakan bahasa sebagai alat penyalurnya.

\subsection{Faktor Penunjang Efektivitas Komunikasi}

Sebagai sebuah proses, komunikasi memiliki prinsip-prinsip yang harus diperhatikan agar komunikasi dapat mencapai keefektifan yang diharapkan. Deddy Mulyana menjelaskan terdapat 12 prinsip komunikasi, yaitu:

(1) Komunikasi adalah proses simbolik.

(2) Setiap perilaku mempunyai potensi komunikasi.

(3) Komunikasi mempunyai dimensi isi dan dimensi hubungan.

(4) Komunikasi berlangsung dalam berbagai tingkat kesengajaan.

(5) Komunikasi terjadi dalam konteks ruang dan waktu.

(6) Komunikasi melibatkan prediksi dari peserta komunikasi.

(7) Komunikasi bersifat sistemik.

(8) Semakin mirip latar belakang sosial budaya, semakin efektif komunikasi.

(9) Komunikasi bersifat nonsekuensial.

(10) Komunikasi bersifat prosesual, dinamis, dan transaksional.

(11) Komunikasi bersifat irreversible.

(12) Komunikasi bukan panasea untuk menyelesaikan berbagai masalah.

Dengan memahami prinsip-prinsip komunikasi tersebut, akan membantu kita memperbaiki kehidupan kita sehari-hari, kawan-kawan, kelompok yang kita masuki, teman-teman sekerja, dan lain sebagainya. Walhasil, petapa pentingnya komunikasi untuk membina hubungan yang baik. Para psikolog berpendapat bahwa kebutuhan utama kita sebagai manusia, dan untuk menjadi manusia yang sehat secara rohaniah, adalah kebutuhan akan hubungan sosial yang ramah, yang hanya bisa terpenuhi dengan membina hubungan yang baik dengan orang-orang lain. Psikolog terkenal, Abraham Maslow, menyebutkan kebutuhan sosial untuk memperoleh rasa aman lewat rasa memiliki dan dimiliki, pergaulan, rasa diterima, memberi dan menerima persahabatan (Tubbs dan Moss,1996:xii).

Selain prinsip-prinsip komunikasi, selanjutnya yang akan menentukan efektivitas proses komunikasi juga bagaimana kita mengemas pesan. Wilbur Schramm (dalam Effendy, 1993:41) menampilkan apa yang ia sebut sebagai "the condition of succsess in communication", yakni kondisi yang harus dipenuhi jika kita menginginkan 
aagar suatu pesan dapat membangkitkan tanggapan yang kita kehendaki, yakni:

(1) Pesan harus dirancang dan disampaikan sedemikian rupa, sehingga dapat menarik perhatian komunikan

(2) Pesan harus menggunakan lambang-lambang tertuju kepada pengalaman yang sama antara komunikator dan komunikan, sehingga samasama mengerti.

(3) Pesan harus membangkitkan kebutuhan pribadi komunikan dan menyarankan beberapa cara untuk memperoleh kebutuhan tersebut.

(4) Pesan harus menyarankan suatu jalan untuk memperoleh kebutuhan tadi yang layak bagi situasi kelompok di mana komunikan berada pada saat ia digerakkan untuk memberikan tanggapan yang dikehendaki.

Ditinjau dari komponen masyarakat sebagai penerima informasi, maka seseorang akan dan dapat menerima sebuah pesan hanya kalau terdapat empat kondisi berikut ini secara simultan:

(1) Ia dapat dan benar-benar mengerti pesan komunikasi.

(2) Pada saat ia mengambil keputusan, ia sadar bahwa keputusannya itu sesuai dengan tujuannya.

(3) Pada saat ia mengambil keputusan, ia sadar bahwa keputusannya itu bersangkutan dengan kepentingannya pribadi.

(4) Ia mampu untuk menepatinya baik secara mental maupun secara fisik (Effendy, 1993:42). Selanjutnya Cutlip dan Center menjelaskan bahwa dalam suatu kegiatan komunikasi untuk menghasilkan efektivitas, perlu diingat hal yang sangat fundamental, yaitu:

(1) Bahwa komunikan terdiri dari orang-orang yang hidup, bekerja, dan bermain satu sama lainnya dalam jaringan lembaga sosial. Karena itu, setiap orang adalah subjek bagi berbagai pengaruh, diantaranya adalah pengaruh dari komunikator.

(2) Bahwa komunikan membaca, mendengarkan, dan menonton komunikasi yang menyajikan pandangan hubungan pribadi yang mendalam

(3) Bahwa tanggapan yang diinginkan komunikator dari komunikat harus memguntungkan bagi komunikan, kalau tidak, ia tidak akan memberikan tanggapan (Effendy, 1993:43).

Selain faktor-faktor di atas yang mempengaruhi keefektifan komunikasi, yakni dari sisi komunikan, terdapat dua faktor dari komunikator yang akan memengaruhi komunikasi yang efektif, yakni kepercayaan pada komunikator (source credibility) dan daya tarik komunikator (souce attractiveness). Kedua hal ini didasarkan posisi komunikan yang akan menerima pesan, yaitu:

(1) Hasrat seseorang untuk memperoleh suatu pernyataan yang benar, jadi komunikator mendapat kualitas komunikasinya sesuai dengan kualitas sampai dimana ia memperoleh kepercayaan dari komunikan, dan apa yang dinyatakannya.

(2) Hasrat seseorang untuk menyamakan dirinya dengan komunikator atau bentuk hubungan lainnya dengan komunikator yang secara emosional memuaskan. Jadi komunikator akan sukses dalam komunikasinya, bila berhasil menarik perhatian komunikan (Effendy, 1993:43).

\subsection{Komunikasi dan Pembangunan}

Perkembangan pemikiran mengenai pemanfaatan dan peranan komunikasi dalam melaksanakan usaha membangun memperlihatkan hubungan yang langsung dengan konsepsi yang dianut dalam merencanakan dan menafsirkan "pembangunan" itu sendiri. Dengan demikian, rumusan tentang pemanfaatan komunikasi ataupun peran yang diharapkan darinya dalam suatu usaha pembangunan amat ditentukan oleh model pembangunan yang dilaksanakan itu sendiri.

Paradigma pembangunan nasional pada masa awalnya identik dengan pembangunan ekonomi. Dalam hal ini, tujuan pembangunan nasional adalah mencapai pertumbuhan ekonomi yang setinggi-tingginya. Dan pembangunan ekonomi dipandang sebagai strategi investasi. Dengan demikian, untuk kepentingan ini, komunikasi dipandang (paling tidak menurut para komunikator) sebagai instrumen kunci bagi 
suksesnya usaha pembangunan ekonomi.

Sejak itu pula segala daya dan kemampuan komunikasi dikerahkan untuk dimanfaatkan sebagai saluran penyampaian informasi dan pengetahuan yang berkaitan dengan aktivitas pembangunan tersebut.

Selanjutnya, dengan berkembangnya teknologi komunikasi, dan juga bergesernya arah pembangunan nasional kepada sektor pertanian dengan berbagai inovasinya, maka komunikasi dilakukan untuk menyampaikan inovasi-inovasi yang ada. Sekali lagi, pada masa ini segala daya dan kemampuan komunikasi (media massa) dijadikan alat dalam rangka difusi inovasi untuk menyukseskan pembangunan pertanian.

Melihat pada pemanfaatan komunikasi dalam proses pembangunan, terlepas dari model pembangunan yang sedang dilaksanakan, maka tentunya komunikasi menjadi sangat penting dalam membantu pembangunan nasional di Indonesia. Dengan kemampuannya dalam membantu proses pembangunan, maka tentunya komunikasi mempunyai tugas-tugas yang diembannya. Wilbur Schramm (dalam Nasution, 1996:85) merumuskan bahwa tugus pokok komunikasi dalam suatu perubahan sosial dalam rangka pembangunan nasional, adalah:

(1) Menyampaikan kepada masyarakat, informasi tentang pembangunan nasional, agar mereka memusatkan perhatian pada kebutuhan akan perubahan, kesempatan dan cara mengadakan perubahan, sarana-sarana perubahan, dan membangkitkan aspirasi nasional.

(2) Memberikan kesempatan kepada masyarakat untuk mengambil bagian secara aktif dalam proses pembuatan keputusan, memperluas dialog agar melibatkan semua pihak yang akan membuat keputusan mengenai perubahan. Memberi kesempatan kepada para pemimpin masyarakat untuk memimpin dan mendengarkan pendapat rakyat kecil, dan menciptakan arus informasi yang berjalan dari bawah ke atas.

(3) Mendidik tenaga kerja yang diperlukan pembangunan, sejak orang dewasa hingga anak-anak, sejak pelajaran baca tulis hingga keterampilan teknis yang mengubah hidup masyarakat.

Catatan tentang komunikasi dalam pembangunan ini masih dapat diperpanjang, terutama karena semakin kompleksnya tuntutan pembangunan itu sendiri. Dari berbagai ulasan yang dikemukakan para ahli, Hedebro (dalam Nasution,1996:86-88) mendaftar 12 peran yang dapat dilakukan oleh komunikasi dalam pembangunan, yaitu:

(1) Komunikasi dapat menciptakan iklim bagi perubahan dengan membujukkan nilai-nilai, sikap mental, dan bentuk perilaku yang menunjang pembangunan.

(2) Komunikasi dapat mengajarkan keterampilanketerampilan baru, mulai dari baca tulis ke pertanian, hingga keberhasilan lingkungan.

(3) Media massa dapat bertindak sebagai pengganda sumber-sumber daya pengatahuan.

(4) Media massa dapat mengantarkan pengalaman-pengalaman yang seolah-olah dialami sendiri, sehingga mengurangi biaya psikis dan ekonomis untuk menciptakan kepribadian yang mobile.

(5) Komunikasi dapat meningkatkan aspirasi yang merupakan perangsang untuk bertindak nyata.

(6) Komuniasi dapat membantu masyarakat menemukan norma-norma baru dan keharmonisan dari masa transisi.

(7) Komuniasi dapat membantu orang lebih condong untuk berpartisipasi dalam pembuatan keputusan di tengah kehidupan bermasyarakat.

(8) Komunikasi dapat mengubah struktur kekuasaan pada masyarakat yang bercirikan tradisional, dengan membawakan pengetahuan kepada masa. Mereka yang memperoleh informasi akan menjadi orang yang berarti, dan para pemimpin tradisional akan tertantang oleh kenyataan bahwa ada orang-orang lain yang juga mempunyai kelebihan dalam hal memiliki informasi.

(9) Komunikasi dapat menciptakan rasa kebangsaan sebagai sesuatu yang mengatasi 
kesetiaan-kesetiaan lokal.

(10) Komunikasi dapat membantu mayoritas populasi menyadari pentingnya arti mereka sebagai warga negara, sehingga dapat membantu meningkatkan aktivitas politik

(11) Komunikasi memudahkan perencanaan dan implementasi program-program pembangunan yang berkaitan dengan kebutuhan pokok.

(12) Komunikasi dapat membuat pembangunan ekonomi, sosial, dan lainnya menjadi suatu poroses yang berlangsung sendiri.

\section{Pembahasan}

\section{1 "Community Action Plan" (CAP) sebagai Pembangunan Partisipatif}

Dalam rangka misi otonomi daerah, ada harapan bahwa perencanaan publik dapat menjadi satu arena interaksi berbagai pihak yang sudah barang tentu dengan memakai landasan prinsipprinsip kesetaraan, kepercayaan, dan tanggung jawab. Ditinjau dari sudut pandang sebagai proses bersama, proses tersebut secara bersamaan akan menjadi satu media pemberdayaan warga.

Sementara itu, jika ditinjau dari sudut pandang output hasil perencanaanpun akan lebih bermanfaat karena merupakan hasil kesepakatan bersama, karena tanpa adanya kesepakatan bersama tersebut, produk perencanaan hampir dapat dipastikan akan tanpa makna.

Oleh karena itu, dalam rangka menunjang pada paradigma pembangunan yang saat ini sedang dicanangkan, yaitu pembangunan partisipatif, maka masyarakat diharapkan lebih berperan aktif dalam merencanakan pembangunan di lingkungannya.

Keputusan Menteri Dalam Negeri No. 9 Tahun 1982, tentang Pedoman penyusunan Perencanaan dan Pengendalian Pembangunan Daerah (P5D) karakter dasarnya sesungguhnya sudah cukup membuka ruang bagi partisipasi masyarakat dalam menentukan produk perencanaan sesuai dengan apa yang mereka butuhkan.

Dalam pada itu, desa sebagai perangkat pemerintahan yang paling dekat dengan masyarakat psosisinya menjadi segnifikan dalam prosesproses pemberdayaan. Kewenangan desa yang lebih di era otonomi daerah ini, sepatutnya menjadikan desa memiliki posisi yang sangat penting bagi keberlangsungan proses transformasi demokrasi kepada masyarakat, seperti yang diamanatkan dalam UU No 22/1999 tentang pemerintahan daerah.

Bagi desa, hal ini tentu juga amat penting. Desa selain penyangga utama dari pemerintahan kabupaten dalam mencapai visi dan misi daerahnya, dalam hal ini juga merupakan institusi yang paling dekat dirasakan langsung oleh masyarakat. Selama ini, memang ada proses perencanaan jangka menengah desa yang dikenal dengan istilah Rencana Pembangunan Jangka Menengah Desa (RPJMD). Namun, hal ini penerapannya dirasakan kurang berjalan. Banyak desa yang belum menerapkan mekanisme ini dengan benar. Bahkan, ternyata masih ada juga desa yang sama sekali tidak menyusun RIJMDnya. Padahal, seperti diuraikan di atas, RPJMD sangat penting sebagai koridor pembangunan desa agar tetap terarah dan berkesinambungan.

Atas dasar itu, pada saat ini diluncurkan sebuah mekanisme yang mencoba mencari solusi atas rantai perencanaan yang terputus tersebut. Salah satunya adalah dengan fasilitasi Perencanaan Prasarana Lingkungan Perumahan/ Pemukiman Partisipatif dengan menggunakan konsep community action plan (CAP) atau rencana tindak komunitas. Konsep ini diharapkan mampu mengakomidir kebutuhan akan penyusunan rencana jangka menengah tersebut, sekaligus juga sebagai panduan dalam menyusun rencana tindak bagi desa.

Di tingkat desa, CAP berupaya untuk melakukan modifikasi terhadap sistem penyususnan perencanaan pembangunan tahunan desa yang diwujudkan dalam dokumen Rencana Pembangunan Jangka Menengah Desa (RPJMD) 5 (lima) tahunan yang selama ini ditenggarai memikili kelemahan. Salah satunya menyangkut pendataan, sinkronisasi data dengan konsistensi kegiatan pembangunan yang dilakukan di desa, dan perumusan rencana tindak.

Adapun maksud CAP ini adalah untuk mempercepat terciptanya kawasan perumahan/ 
pemukiman yang memenuhi standar (rumah layak huni dalam lingkungan sehat, tertata dan terencana) melalui upaya peningkatan kualitas.

Selanjutnya, tujuan diluncurkannya program pendampingan atau partisipatif masyarakat melalui CAP ini adalah:

(1) Membantu masyarakat agar mampu mengenali dan menggali potensi serta permasalahan lingkungan tempat tinggalnya dan mampu mencari upaya pemecahannya.

(2) Membantu masyarakat agar mampu menyusun rencana tindak di tingkat komunitas yang secara konsisten dapat diacu untuk meningkatkan taraf kehidupannya.

(3) Menyediakan pedoman bagi para pelaksana di daerah (kota dan Kabupaten) dalam mewujudkan suatu community action plan yang disusun secara partisipatif.

Pelaksanaan program pembangunan partisipatif melalui community action plan (CAP) ini, meliputi kegiatan sebagai berikut:

(1) Sosialisasi dalam rangka memberikan pemahaman (pemberian muatan detail) kepada masyarakat melalui berbagai forum. Dalam kegiatan ini diharapkan masyarakat paham dan bersedia menerima program.

\section{Gambar 1. Struktur Organisasi Pembangunan Partisipatif}

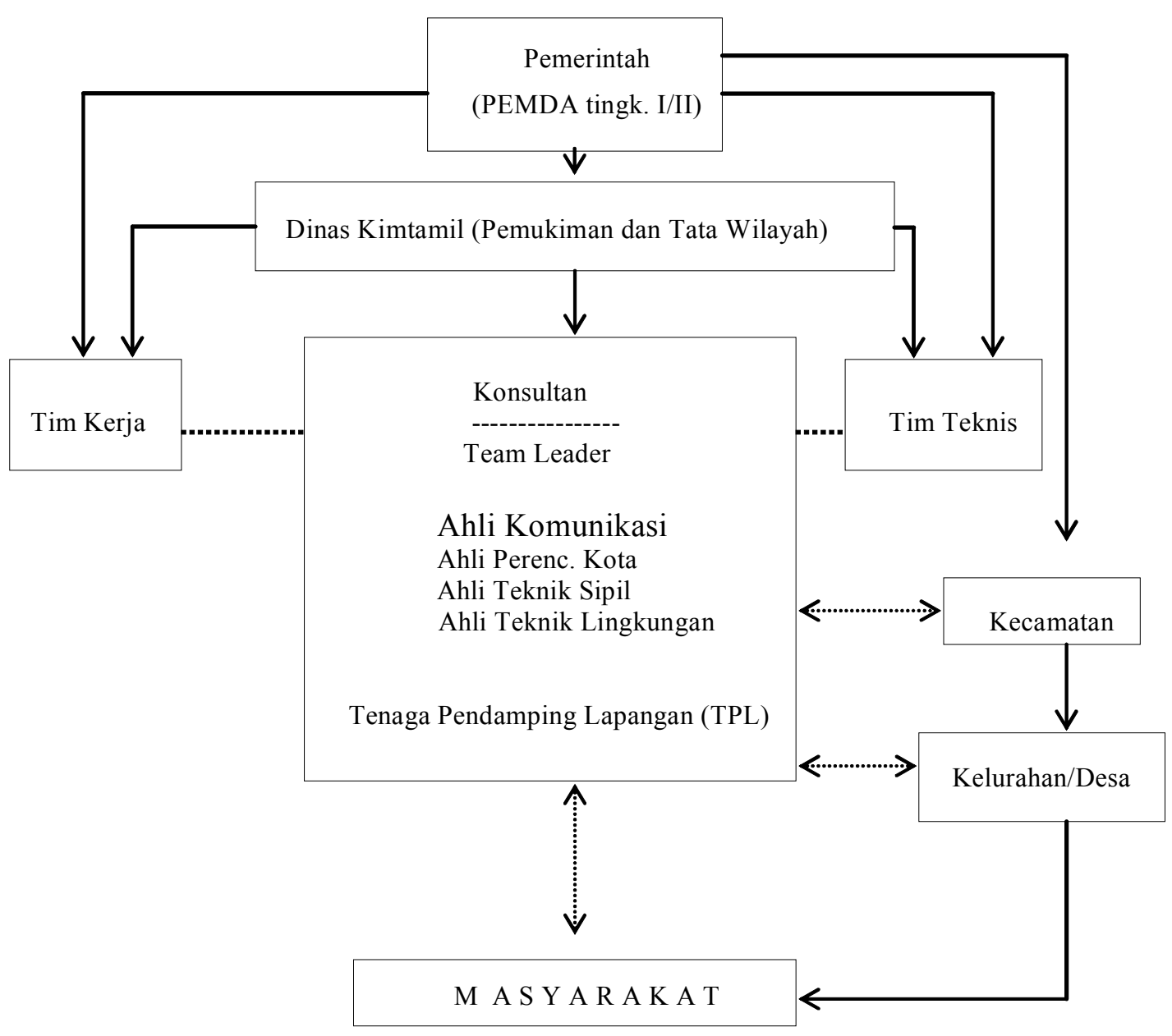


(2) Pendampingan masyarakat bersama TPM (Kader Penggerak Masyarakat) dalam menggali permasalahan dan potensi di desa.

(3) Pendampingan masyarakat dalam memfasilitasi penyusunan rencana tindak komunitas (community action plan/CAP) melalui proses perencanaan yang partisipatif, dengan tahapan kegiatan sebagai berikut:

(a) Rembuk warga I, dikenal dengan istilah Focus Group Discussion (FGD) yang akan menggali aspirasi dari masyarakat, dan membahas masalah dan potensi di lingkungan tempat tinggalnya.

(b) Pelaksanaan Survei Kampung Sendiri (SKS).

(c) Rembug warga II, yang diselenggarakan untuk merangkum dan mendiskusikan ulang masalah dan potensi serta usulan masyarakat setelah dilakukan SKS dan membuat prioritasprioritas.

Dalam rangka pelaksanaan pembangunan partisipatif melalui program CAP ini pemerintah dibantu oleh konsultan melalui beberapa tenaga ahli dari berbagai disiplin ilmu. Struktur organisasi pembangunan partisipatif tersebut seperti pada Gambar 1.

\subsection{Peranan Komunikasi dalam Pembanguanan Partisipatif}

Melihat pada penjelasan tentang bagaimana program pembangunan yang berlandaskan pada partisipatif dari masyarakat ini, di mana dalam rangkaian kegiatannya lebih banyak menitikberatkan pada pendampingan melalui diskusi (komunikasi). Hal ini menandakan bahwa peranan komunikasi begitu besar dalam rangkaian kegiatan pembangunan partisipatif ini.

Hal ini sejalan dengan peran komunikasi dalam pembangunan dari Hedebro yang menyatakan bahwa dengan komunikasi dapat menciptakan iklim bagi perubahan dengan membujukkan nilainilai, sikap mental, dan bentuk perilaku yang menunjang pembangunan. Selanjutnya, komunikasi juga dapat meningkatkan aspirasi yang merupakan perangsang untuk bertindak nyata.

Di samping hal tersebut di atas, komunikasi dapat membantu masyarakat menemukan normanorma baru dan keharmonisan dari masa transisi. Komunikasi dapat juga membantu orang lebih condong untuk berpartisipasi dalam pembuatan keputusan di tengah kehidupan bermasyarakat.

Sejalan dengan Hedebro, maka McClelland (dalam Nasution, 1996:99) menjelaskan bahwa dorongan psikologis yang memotivasi suatu masyarakat untuk mencapai kemajuan harus dimulai dengan mengubah sikap mental (attitude) para anggota masyarakat. Kebutuhan untuk mencapai sesuatu (need for achievement atau $n$ / Ach) merupakan dorongan pada seseorang individu untuk menghadapi tantangan, mengatasi oposisi, dan berhasil menanggulangi berbagai kesulitan. Karena itu, peranan komunikasi dalam memotivasi masyarakat untuk menumbuhkan kebutuhan mecapai sesuatu berperan begitu penting.

Kemudian, dalam model pembangunan partisipatif ini terjadi pergeseran makna dari kata pembangunan itu sendiri, di mana pada beberapa tahun yang lalu pembangunan didefinisikan sebagai "apa yang dikerjakan pemerintah untuk (dan bagi) rakyatnya", sehingga keputusankeputusan tentang pembangunan yang diperlukan dibuat oleh pemerintah kemudian pelaksananya melalui program-program pembangunan yang dijalankan oleh pegawai-pegawai pemerintah yang berhubungan dengan masyarakat. Pendekatan atas-bawah dalam pembangunan seperti ini mengisyaratkan bahwa peranan satu arah dalam komunikasi.

Tentu saja, pembangunan partisipatif memberikan peranan yang amat berbeda kepada komunikasi dibandingkan dengan pedekatan pembangunan atas-bawah di masa lalu. Dalam pembangunan partisipatif, terjadi perubahan paradigma komunikasi menjadi bawah-atas. Pembangunan diawali dari perencanaan berdasarkan aspirasi masyarakat, di mana pada akhirnya reaslisasinya pun akan sesuai dengan kebutuhan yang benar-benar dirasakan oleh masyarakat. Hal ini sejalan dengan tugas yang emban oleh komunikasi menurut Wilbur Schramm (dalam Nasution, 1996:85), yang menjelaskan bahwa 
dengan pembangunan yang partisipatif memberikan kesempatan kepada masyarakat untuk mengambil bagian secara aktif dalam proses pembuatan keputusan, memperluas dialog agar melibatkan semua pihak yang akan membuat keputusan mengenai perubahan. Memberi kesempatan kepada para pemimpin masyarakat untuk memimpin dan mendengarkan pendapat rakyat kecil, dan menciptakan arus informasi yang berjalan dari bawah ke atas.

Kita dapat melihat bagaimana komunikasi antar persona menjadi teknik komunikasi yang dominan dilakukan dalam rangka pendampingan masyarakat. Hal ini jauh berbeda dari model pembangunan yang lalu, di mana teknik komunikasi yang banyak dilakukan adalah komunikasi melalui media massa, sehingga komunikasi berjalan satu arah.

Dengan komunikasi antarpesona, para peserta diskusi dalam merencanakan pembangunannya akan lebih terbuka untuk menyampaikan segala aspirasi dan permasalahan yang dihadapinya. Di samping itu, para peserta komunikasi akan melihat secara langsung reaksi yang bersifat nonverbal, sehingga suasana yang terjadi menjadi lebih akrab. Oleh karena itu, pesan dalam pelaksanaan pembangunan partisipatif akan lebih mudah dan cepat diterima, apabila pesan-pesan tersebut memiliki faktor-faktor sebagai berikut:

(1) Sesuai dengan kebutuhan yang dirasakan masyarakat

(2) Informasi yang tepat dengan keadaan mereka

(3) Dapat diterima dan cocok dengan kebudayaan kelompok masyarakat

(4) Informasi yang benar secara teknik/ilmiah Selain itu, dengan pelaksanaan diskusi (komuniasi tatap muka) dimungkinkan adanya peningkatan partisipasi semua pihak yang ikut serta dalam proses diskusi tersebut, demi tercapainya suatu fokus bersama dalam memandang permasalahan yang dihadapi.

Agar komunikasi yang dilakukan lebih berhasil mencapai sasarannya, serta dapat menghindarkan kemungkinan-kemungkinan efek yang tidak diharapkan, tentunya harus mempertimbangkan hal-hal yang disorot (menjadi fokus) tadi. Menurut
Rogers dan Adhikarya (dalam Nasution, 1996:149150) kesenjangan efek yang ditimbulkan oleh kekeliruan cara-cara komunikasi dapat diperkecil apabila strategi komunikasi yang dilakukan mencakup prinsip-prinsip berikut:

(1) Penggunaan pesan yang dirancang khusus untuk khalayak yang spesifik. Sebagai misal, bila hendak menjangkau khalayak miskin pada perumusan pesan, tingkat bahasa, gaya penyajian, dsb, disusun begitu rupa agar dapat dimengerti dan serasi dengan konsisi mereka. Penggunaan pendekatan "narrao casting" atau melokalisir penyampaian pesan bagi kepentingan khalayak. Lokalisasi di sini berarti disesuaikannya penyampaian informasi yang dimaksud dengan situasi kesempatan di mana khlayak berada.

(2) Mengaktifkan keikutsertaan agen-agen perubahan (kader) yang berasal dari kalangan masyarakat sendiri sebagai petugas lembaga pembangunan yang beroperasi di kalangan mereka sendiri.

(3) Diciptakan dan dibina cara-cara atau mekanisme bagi keikutsertaan khalayak (sebagai pelaku-pelaklu pembangunan itu sendiri) dalam proses pembangunan, yaitu sejak tahap perencanaan sampai evaluasinya. Melihat pada apa yang dijelaskan oleh Rogers dan Adhikarya di atas, maka inilah yang dilakukan oleh pembangunan partisipatif saat ini dengan adanya ahli komunikasi dalam menyosilisasikan dan pelaksanaan pendampingan masyarakat dalam merencanakan pembangunan yang ada di lingkungannya melalui pembuatan Rencana Pembangunan Jangka Menengah Desa (RPJMD).

\section{Kesimpulan}

Dalam otonomi daerah pembangunan mengalami pergeseran paradigma dengan adanya pembangunan partisipatif, yaitu pembangunan yang dilandaskan para partisipasi yang aktif dari lapisan masyarakat terendah (di desa), dimulai dari perencanaan, rencana tindak, sumber dana, dan evaluasi.

Dalam pembangunan partisipatif melalui program community action plan (CAP), komunikasi 
memegang peranan yang sangat penting, yaitu pada proses sosialisasi dan diskusi-diskusi yang dilakukan dalam mengidentifikasi permasalahan dan potensi, menjembatani proses kemitraan dalam mendukung program CAP, dan lain sebagainya.

Dengan demikian, para sarjana komunikasi memegang peranan penting dalam proyek-proyek fisik, yang selama ini sering dipersepsi hanya merupakan lahan kerja bagi para sarjana teknik.

\section{Daftar Pustaka}

DeVito, Joseh A. 1997. Komunikasi Antar Manusia; Kuliah Dasar, Terj.Agus Maulana, edisi kelima. Jakarta: Professional Books.

Nasution, Zulkarimein. 1996. Komunikasi Pembangunan; Penganalan Teori dan Penerapannya, edisi revisi. Jakarta: Rajagrafindo Persada.

Prasetyo, Budi. 2004. Materi Prinsip, Metoda dan Teknik Pendampingan Masyarakat; Modul Pelatihan TPM. Bandung: Kimpraswil.
Rogers, Everett.M. 1984. Komunikasi dan Pembangunan; Perspektif Kritis. Jakarta: LP3ES.

Susanto, Phil, Astrid. 1995. Sosiologi Pembangunan, Jakarta: Binacipta.

Tubbs,Stewart L \& Sylvia Moss,1996, Human Communication; Prinsip-Prinsip Dasar

Buku Pertama,Terj. Deddy Mulyana, Bandung, Remaja Rosdakarya.

Tjokrowinoto, Moeljarto, 1996, Pembangunan; Dilema dan Tangtangan, Yogyakarta, Pustaka Pelajar.

\section{Sumber lain:}

Kerangka Acuan Kerja; Kegiatan Fasilitasi Perencanaan Prasarana Lingkungan Perumahan/Pemukinan Pertisipatif di Kabupaten Bandung

Departemen Pemukinan dan Prasarana WiliayahDirektorat Jenderal Perumahan dan Pemukiman. 2001. Petunjuk Pelaksanaan Peremajaan Lingkungan Pemukinan Kumuh di Perkotaan dan Pedesaan (dengan konsep Tridaya) 